\title{
High Molecular Weight Synthetic Polypeptides Soluble in Commercial Aprotic Solvents ${ }^{\dagger}$
}

\author{
Masanao OYA and Hiroko K YOTANI* \\ Department of Industrial Chemistry, College of Technology. \\ Gunma University, Tenjin-cho. Kiryu 376, Japan \\ * Research Institute for Polymers and Textiles, \\ Yatabe-cho, Tsukuba-gun, Ibaraki 305, Japan
}

(Received March 16, 1985)

\begin{abstract}
Copolypeptides soluble in commercial aprotic solvents were synthesized by the copolymerization of $N$-carboxy- $\alpha$-amino acid anhydrides. Optical rotatory dispersion of the polymerization solutions was measured to determine the relationship between conformation of copolypeptides and solubility in the polymerization solvents. The solubility of the copolypeptides in the aprotic solvents was affected by the pendant groups of the polypeptides, but scarcely by the irregularity in the D- and L-amino acid sequence on the main chain of polypeptides.
\end{abstract}

KEY WORDS Copolypeptides / Conformation / Solubility / ORD /

Various copolypeptides with high molecular weights have been synthesized by many workers. ${ }^{1-5} \mathrm{~A}$ few of them including $\operatorname{poly}(\gamma-$ benzyl glutamate) (poly(OBZlGlu)), poly $(\gamma-$ ethyl glutamate) (poly(OEtGlu)), and poly( $N^{\varepsilon}$-carbobenzoxy lysine) (poly(ZLys)), and $\operatorname{poly}\left(N^{\delta}\right.$-carbobenzoxy ornithine) (poly(ZOrn)) are soluble in aprotic commercial solvents such as dichloromethane, dichloroethane, and benzene, though soluble in strong acidic organic solvents such as dichloroacetic acid, trifluoroacetic acid, trifluoroethanol, and hexafluoroisopropanol. Physicochemical studies of polypeptides have been undertaken mostly in strong acidic solvents. Very few conformational studies in aprotic solvents have been reported. High strength film of polypeptides useful for industrial application can hardly be cast from solutions of acidic solvents. In addition, these solvents are very expensive and toxic. These problems have long prevented the growth of polypeptides as commercial products, except poly(glutamic acid ester)s.

We previously reported that a copolypeptide consisting of equimolar of $N^{\varepsilon}$-carbobenzoxy lysine (ZLys) with $\beta$-benzyl aspartate (OBzl Asp) is soluble in acetonitrile which is a non solvent for each homopolypeptides. ${ }^{6}$

The conformation of $\operatorname{poly}(\beta$-benzyl L-aspartate) in a film has been reported to be a right handed $\alpha$-, left handed $\alpha$-, or left handed $\omega$-helix, depending on solvents for casting. ${ }^{7,8}$ ZLys $N$-carboxy amino acid anhydride (NCA) was polymerized in most aprotic solvents to produce a polypeptide with the $\alpha$-conformation. ${ }^{5}$ These results indicate that copolypeptides soluble in aprotic solvents can be prepared by copolymerization of two NCAs which produce copolypeptides with different

† A part of this work was presented at the 1st SPSJ International Polymer Conference: Kyoto, Japan, August 2024, 1984, Abstracts No. 23A19; and at the 48th; National Meeting of Chemical Society Japan, Sapporo, August 1983, Abstracts No. 4Y14.

Abbreviations of amino acids and their derivatives in this paper are those recommended by the IUPAC-IUB Commission on Biochemical Nomenclature. 
Table I. Copolymerization of $N$-carboxy amino acid anhydrides

\begin{tabular}{|c|c|c|c|c|c|c|c|c|c|}
\hline \multirow{3}{*}{ No. } & \multirow{3}{*}{ NCAs } & \multicolumn{3}{|c|}{ Polymerization system } & & & \multicolumn{3}{|c|}{ Copolypeptides formed } \\
\hline & & \multirow[b]{2}{*}{ Ratio } & \multirow{2}{*}{$\begin{array}{c}\text { Concentration } \\
\text { of initial } \\
\text { monomers } / \mathrm{moll}^{-1}\end{array}$} & \multirow{2}{*}{$\begin{array}{l}\text { Form of } \\
\text { polymerized } \\
\text { system }\end{array}$} & \multicolumn{2}{|c|}{ ORD } & \multirow{2}{*}{$\begin{array}{l}\eta_{\mathrm{sp}} / c(\mathrm{~g} / 100 \mathrm{ml} \\
\text { in } \mathrm{DCA})^{\mathrm{a}}\end{array}$} & \multicolumn{2}{|c|}{ Films } \\
\hline & & & & & $a_{0}$ & $b_{0}$ & & $\begin{array}{l}\text { Tensile strength } \\
\qquad / \mathrm{kg} \mathrm{mm}^{-2}\end{array}$ & $\begin{array}{l}\text { Young's modulus } \\
/ \mathrm{kg} \mathrm{mm}^{-2}\end{array}$ \\
\hline 1 & OBzAsp/Ala & $1 / 9$ & 0.15 & Sponge & & & $1.98(0.50)$ & & \\
\hline 2 & OBzAsp/Ala & $1 / 3$ & 0.15 & Gel & & & $1.08(0.51)$ & $5.5^{\mathrm{b}}$ & 52 \\
\hline 3 & OBzAsp/Ala & $1 / 1$ & 0.15 & $\begin{array}{l}\text { Colloidal } \\
\text { solution }\end{array}$ & +270 & -540 & $1.12(0.49)$ & 7.5 & 114 \\
\hline 4 & OBzAsp/Ala & $3 / 1$ & 0.15 & Solution & -200 & -400 & $0.59(0.52)$ & 2.9 & 179 \\
\hline 5 & OBzAsp/Ala & $9 / 1$ & 0.15 & $\begin{array}{l}\text { Precipitation } \\
\text { of polymer }\end{array}$ & & & $0.41(0.51)$ & & \\
\hline 6 & OBzAsp/DL-Ala & $1 / 2$ & 0.15 & Suspension & & & & & \\
\hline 7 & OBzAsp/DL-Ala & $1 / 1$ & 0.15 & Solution ${ }^{\mathrm{c}}$ & -230 & -150 & $0.32(0.50)$ & & \\
\hline 8 & OBzAsp/DL-Ala & $3 / 1$ & 0.15 & Solution & $-300^{d}$ & $-100^{\mathrm{d}}$ & $0.40(0.46)$ & 6.0 & 208 \\
\hline 9 & OBzGlu/DL-Ala & $3 / 1$ & 0.25 & Slurry & & & $0.38(0.52)$ & 1.8 & 102 \\
\hline 10 & OBzGlu/DL-Ala & $1 / 1$ & 0.25 & Solution & -230 & -145 & $0.38(0.51)$ & 1.4 & 33 \\
\hline 11 & Met/OBzAsp & $3 / 1$ & 0.13 & Solution & +90 & -610 & $2.42(0.54)$ & 3.6 & 107 \\
\hline 12 & Met/OBzAsp & $1 / 1$ & 0.13 & $\mathrm{Gel}^{\mathrm{e}}$ & -340 & -420 & $1.85(0.50)$ & 2.0 & 80 \\
\hline 13 & Met/OBzAsp & $1 / 3$ & 0.13 & $\mathrm{Gel}^{\mathrm{f}}$ & +40 & -400 & $1.44(0.49)$ & 0.4 & 95 \\
\hline 14 & OBzAsp/Leu & $3 / 1$ & 0.09 & $\begin{array}{l}\text { Precipitation } \\
\text { of polymer }\end{array}$ & & & & & \\
\hline 15 & OBzAsp/Leu & $1 / 1$ & 0.09 & $\begin{array}{l}\text { Colloidal } \\
\text { solution }\end{array}$ & -205 & -575 & $1.10(0.53)$ & 6.4 & 142 \\
\hline 16 & OBzAsp/Leu & $1 / 3$ & 0.09 & Gel & $\begin{array}{l}-420 \\
+110^{\mathrm{h}} \\
+20^{\mathrm{i}}\end{array}$ & $\begin{array}{l}+80 \\
-210^{\mathrm{h}} \\
-120^{\mathrm{i}}\end{array}$ & $0.45(0.50)^{\mathrm{g}}$ & & \\
\hline
\end{tabular}




\begin{tabular}{|c|c|c|c|c|c|c|c|c|c|}
\hline 17 & Met-Leu & $2 / 1$ & 0.20 & $\mathrm{Gel}^{\mathrm{j}}$ & $\begin{array}{c}-1300 \\
-100^{k}\end{array}$ & $\begin{array}{c}+1900 \\
-110^{k}\end{array}$ & $2.93(0.55)$ & 7.9 & 119 \\
\hline 18 & Met/Leu & $1 / 1$ & 0.40 & Gel & $-100^{1}$ & $-450^{1}$ & $6.10(0.55)$ & 2.7 & 118 \\
\hline 19 & Met/Leu & $1 / 3$ & 0.40 & $\mathrm{Gel}^{\mathrm{m}}$ & $+400^{\mathrm{m}}$ & $-640^{\mathrm{m}}$ & $5.70(0.55)$ & 5.1 & 79 \\
\hline 20 & ZLys/OBzAsp & $3 / 1$ & 0.10 & Solution & $+140^{n}$ & $-600^{n}$ & $0.50(0.55)$ & 0.4 & 100 \\
\hline 21 & ZLys/OBzAsp & $1 / 1$ & 0.10 & Solution & +120 & -540 & $0.58(0.54)$ & 0.6 & 29 \\
\hline 22 & ZLys/OBzAsp & $1 / 3$ & 0.10 & Solution & -220 & -595 & $0.40(0.25)$ & No strength & \\
\hline 23 & ZOrn/OBzAsp & $3 / 1$ & 0.15 & Solution & +100 & -450 & $0.70(0.49)$ & 0.9 & 22 \\
\hline 24 & ZOrn/OBzAsp & $1 / 1$ & 0.15 & Solution & +60 & -500 & $0.60(0.49)$ & 1.9 & 63 \\
\hline 25 & ZOrn/OBzAsp & $1 / 3$ & 0.15 & Solution & -300 & -420 & $0.43(0.43)$ & 2.0 & 72 \\
\hline 26 & SBzCys/OBzAsp & $3 / 1$ & 0.15 & $\mathrm{Gel}^{\circ}$ & & & $0.53(0.51)$ & & \\
\hline 27 & SBzCys/OBzAsp & $1 / 1$ & 0.15 & $\mathrm{Gel}^{\mathrm{p}}$ & & & $0.46(0.50)$ & No strength & \\
\hline 28 & SBzCys/OBzAsp & $1 / 3$ & 0.15 & Solution & -520 & -540 & $0.64(0.50)$ & 3.0 & 112 \\
\hline
\end{tabular}

${ }^{\text {a }}$ Dichloroacetic acid.

${ }^{b}$ Film was made by pressing the gel.

c Slightly opaque solution.

d $b_{0}=-270$ for a solution of separated copolypeptide No. 8 under the same conditions.

e Soft and pale white. Solution by addition of half volume of $\mathrm{C}_{6} \mathrm{H}_{6}$ to the system.

f Solution by addition of the same volume of $\mathrm{C}_{6} \mathrm{H}_{6}$ to the system.

I In trifluoroacetic acid.

h At $70^{\circ} \mathrm{C}, c=0.058 \mathrm{~g} \mathrm{ml}^{-1}$

i Cool from $70^{\circ} \mathrm{C}$ to $20^{\circ} \mathrm{C}, c=0.059 \mathrm{~g} \mathrm{ml}^{-1}$.

j Solution by addition of half volume of $\mathrm{C}_{6} \mathrm{H}_{6}$, Gel had IR absorption at 1650,1635 , and $1525 \mathrm{~cm}^{-1}$.

${ }^{k}$ For the solution by addition of half volume of $\mathrm{C}_{6} \mathrm{H}_{6}$ to the system at $60^{\circ} \mathrm{C}$.

${ }^{1}$ For the solution by addition of two volume of $\mathrm{C}_{6} \mathrm{H}_{6}$ to the system.

m Hard elastic gel, ORD for the solution by addition of the same volume of $\mathrm{C}_{6} \mathrm{H}_{6}$ to the system.

${ }^{\mathrm{n}} a_{0} ;+90$ and $b_{0} ;-345$ was observed for the solution at a concentration of $0.021 \mathrm{moll}^{-1}$.

- Hard gel; film was not casted.

${ }^{p}$ Soft clear gel; film was casted from the solution by addition of the same volume of $\mathrm{C}_{6} \mathrm{H}_{6}$ to the system. 
conformation. This may also indicate that copolypeptides with bulkier pendant groups have better solubility in aprotic solvents. Generally, the inter- and intra-molecular hydrogen bonds of the peptide main chain affect the solubility of polypeptides. Copolypeptides obtained from different NCAs which produce polypeptides with different conformations must have less hydrogen bonds.

In this work, the copolymerization of various NCAs was initiated with triethylamine in dichloroethane to obtain soluble and high molecular weight copolypeptides.

\section{EXPERIMENTAL}

Preparation of NCAs was carried out as reported previously. ${ }^{4}$ NCA were copolymerized in dichloroethane at concentrations shown in Table I at $30^{\circ} \mathrm{C}$ for $144 \mathrm{~h}$. Optical rotatory dispersion (ORD) of polymerization solution was measured at wavelengths of 650 to $250 \mathrm{~nm}$ at about $20-25^{\circ} \mathrm{C}$ after completion of polymerization. Moffit parameters, $a_{0}$ and $b_{0}$, were calculated with reference to literatures. ${ }^{9,10}$ Films of copolypeptides were made by evaporation of the solution of copolypeptide or polymerization solution on a flat glass plate. Films of $10-15 \mathrm{~mm}$ width and 0.05 $0.2 \mathrm{~mm}$ thick were used for measurement of tensile strength by Tensilon UTM-1.

\section{RESULTS AND DISCUSSION}

The polymerization conditions and some properties of copolypeptides formed are shown in Table I.

Ala NCA polymerizes in most aprotic solvents to produce poly(Ala) with the $\alpha$ conformation, while it polymerizes in dimethyl sulfoxide (DMSO) to produce the $\beta$-conformational poly(Ala). ${ }^{5}$ The conformation of poly(OBzlAsp) depends on the polymerization solvent, temperature, and aftertreatment of polymer. ${ }^{8}$ Copolymerization system of Ala NCA with OBzAsp NCA in a ratio $1 / 1$ gave a viscous solution after the polymerization. The Moffit parameter $b_{0}$ of the copolypeptide thus obtained was -540 which corresponded to a helix content of $85 \% \%^{9,10}$ The copolymerization of Ala NCA with OBzAsp NCA in a ratio $1 / 3$ gave a solution stable for a long period. The resulting solution has $b_{0}$ of -440 .

Copolypeptide No. 2 has infrared absorption at $1657,1305,615,530$, and $375 \mathrm{~cm}^{-1}$ characteristic of the $\alpha$-conformation, and weak absorption at 1695,1630 , and $1245 \mathrm{~cm}^{-1}$ characteristic of the $\beta$-conformation. Accordingly, the conformation of this copolypeptide is in the $\alpha$-conformation containing a small amount of the $\beta$-conformation. Copolypeptide No. 3 (OBzlAsp/Ala; 1/1) shows weak absorption at 1305 and no absorption at 1275 $\mathrm{cm}^{-1}$ characteristic of the crystalline bands of $\alpha$-conformational poly(Ala). ${ }^{11}$ This copolypeptide also shows the band at $1250 \mathrm{~cm}^{-1}$ which is ascribed to poly(DL-Ala), and weak absorption at 1230 and $445 \mathrm{~cm}^{-1}$, which is ascribed to the $\beta$-conformation. ${ }^{12,13}$ No strong peaks of poly(OBzAsp $)^{14}$ were observed. Therefore, copolypeptide No. 3 is in the helix with a small amount of the $\beta$-conformation and has low crystallinity. The spectrum of copolypeptide No. 4 (OBzlAsp/Ala; 3/1) was similar to that of No. 3. This would mean that the conformation of these copolypeptides is affected by the strong stability of the helix of poly(Ala). Dried copolypeptides No. 3 and 4 could be easily dissolved again in dichloroethane.

It has generally been considered that the main chain of copolypeptides containing DLamino acid residues is in a more random structure than those containing L-amino acid residue only. The random structure results in a decrease of aggregation power of molecule and increase of solubility of polypeptides. However, copolypeptides of DL-Ala with OBzlAsp were less soluble than those of all corresponding L-amino acids only, in spite of a fact that helix contents of copolypeptides No. 7 and 8 (OBzlAsp/DL-Ala; 1/1 and 3/1) 
were less than those of No. 3 and 4 (OBzlAsp/Ala; $1 / 1$ and 3/1). High strength film could be cast from the polymerization solution in a ratio 3/1 of OBzlAsp/DL-Ala.

In copolypeptides No. 6, 7, and 8, the $520 \mathrm{~cm}^{-1}$ band due to the $\alpha$-helix-like conformation of (Ala-Ala-Al-D-Ala) ${ }_{n}$ was observed. ${ }^{15}$ The band at 450 or $445 \mathrm{~cm}^{-1}$ due to the coiled or $\beta$-conformational poly(Ala) was observed in spectra of copolypeptides No. 7 and 8. For copolypeptides No. 6 and 7, however, only two weak bands of poly(OBzlAsp) in the vicinity of $660 \mathrm{~cm}^{-1}$ were observed. These indicate that these copolypeptides have a right handed helix including a small amount of the $\beta$ - or random conformation.

The helicity and solubility of poly $(\gamma$-benzyl L-glutamate) (poly(OBzlGlu)) in aprotic solvents such as dichloroethane, dichloromethane, chloroform, and dioxane are higher than those of poly(OBzlAsp). Copolypeptide of OBzlAsp with DL-Ala in a ratio 3/1 (No. 8) was obtained as solution. On the other hand, the copolypeptide of OBzlGlu with DL-Ala (No. 9) was obtained as slurry. Copolypeptide No. 9 (OBzlGlu/DL-Ala; 3/1) has bands at 620 and $410 \mathrm{~cm}^{-1}$ due to the $\alpha$-helical poly(OBzlGlu) but no bands at $530 \mathrm{~cm}^{-1}$ due to the coiled one. $^{12-14}$ In the case of copolypeptide No. 10 (OBzlGlu/DL-Ala; 1/1), 660 and $530 \mathrm{~cm}^{-1}$ bands due to the $\beta$-conformation were observed and bands due to the $\alpha$-conformation were very weak. These results indicate that copolypeptide No. 9 is in a helical form and No. 10 in a coiled form. The conformation of copolypeptide No. 10 observed by infrared spectrum in the film state is comparable with that obtained by ORD measured in the polymerization solution.

When methionine (Met) NCA is polymerized in various aprotic solvents, poly(Met) is produced in a stable $\alpha$-helical conformation. ${ }^{17-19}$ As is shown in Table I, copolypeptides of Met with OBzlAsp (No. 11-13) were obtained in a helical conformation in the polymerization solution. Copolypeptides No.
11 and 12 (Met/OBzlAsp; 3/1 and 1/1) show the $420 \mathrm{~cm}^{-1}$ band characteristic of $\alpha$-conformational sequential copolypeptides of Met with Ala or Leu, ${ }^{20}$ but no $410 \mathrm{~cm}^{-1}$ band due to $\alpha$-poly(Met). ${ }^{21}$ In these copolypeptides, the bands at 602 and $614 \mathrm{~cm}^{-1}$ characteristic of right and left handed $\alpha$-conformational poly(OBzlAsp), respectively, were not clear. However, both copolypeptides have absorption bands at 620 and $610 \mathrm{~cm}^{-1}$ due to amide $\mathrm{V}$ band of the $\alpha$-helix. Thus, copolypeptides No. 12 and 13 consist of the $\alpha$-helical conformation with random sequence and no block configuration of amino acids. For copolypeptide No. 13 (Met/OBzlAsp; 1/3) a broad absorption appeared at about $600 \mathrm{~cm}^{-1}$ due to the right handed $\alpha$-poly(OBzlAsp).

The solubility of poly(leucine) (poly(Leu)) is higher than that of poly(Ala) or poly(DL-Ala) in aprotic solvents. Copolypeptide No. 15 (OBzlAsp/Leu; 1/1) was obtained in a soluble form in the polymerization solution which showed $b_{0}$ of -575 . Copolypeptide No. 16 (OBzlAsp/Leu; 1/3) was obtained in a gelatinous form. The value of $b_{0}$ was +80 , indicating that polymer No. 16 was not in the $\alpha$ conformation. The infrared spectra of the polymerization solution of No. 16 have absorption at $1655,1648,1545$, and $470 \mathrm{~cm}^{-1}$, which are characteristic of the mixture of coiled and $\beta$-form copolypeptides. Copolypeptide No. 15 in the film form gave bands at 1660 and $615 \mathrm{~cm}^{-1}$, which are characteristic of $\alpha$-poly(Leu), and also bands at 890, 490, and $450 \mathrm{~cm}^{-1}$ which are due to the right handed $\alpha$ poly(OBzlAsp). This indicates that copolypeptide No. 15 consists of right handed $\alpha$ helical segments of poly(OBzlAsp) and poly(Leu). Absorption at $780 \mathrm{~cm}^{-1}$ due to the right handed poly(OBzlAsp) disappeared. The copolypeptide No. 16 gave no IR absorption at 490 and $450 \mathrm{~cm}^{-1}$.

Although L-Ala NCA could be polymerized in DMSO to produce poly(Ala) in the $\beta$ conformation, L-Leu NCA was polymerized in DMSO to produce poly(Leu) in the $\alpha$-con- 
formation. ${ }^{4}$ This suggests that the $\alpha$-helix of poly(Leu) is more stable than that of poly(Ala). The high helix forming power of Leu residues influences the conformation of the copolypeptides of Leu with OBzlAsp. Copolypeptide No. 17 (Met/Leu; 1/2) was obtained in a swollen gel form in polymerization solution, which became a colloidal solution by addition of a half volume benzene followed by heating at $60^{\circ} \mathrm{C}$. Values of $b_{0}$ of this gel and of the colloidal solution were +1900 and -110 , respectively. The infrared spectra of the swollen gel No. 17 at $24^{\circ} \mathrm{C}$ gave the $1650,1635,1545$, and $1528 \mathrm{~cm}^{-1}$ bands due to copolypeptide in the mixed $\alpha$ - and $\beta$ conformation. Polymerization solution No. 18 and 19 (Met/Leu; 1/1 and 1/3) gave gels in which the copolypeptides were in a highly helical conformation. Solutions of these copolypeptides were obrained either by heating or by adding benzene to the gels and they were able to cast to give films with high tensile strength. Copolypeptide No. 17 showed the bands at 1660,1545 , and $615 \mathrm{~cm}^{-1}$ characteristic of the $\alpha$-helical conformation, but very weak absorption at 420 and $430 \mathrm{~cm}^{-1}$ corresponding to $\alpha$-helical poly(Met) and poly(Leu), respectively. This indicates that the helix of No. 17 was different from those of $\alpha$ conformational poly(Met) and poly(Leu). The copolypeptide of DL-Ala and L-Leu in a 1/1 ratio was obtained in a gel form in the polymerization solution, and gave a viscosity of 2.0 $\left(c=0.5 \mathrm{~g} \mathrm{dl}^{-1}\right.$ in DCA). This gel became a solution with refluxing, and could be cast to make a film having $6.1 \mathrm{~kg} \mathrm{~mm}^{-2}$ in tensile strength and $178 \mathrm{~kg} \mathrm{~mm}^{-2}$ Young's modulus. Infrared spectrum of this film has the 1655 , $1545,1300,700,645,620,470,420$, and $396 \mathrm{~cm}^{-1}$ bands due to the $\alpha$-conformation. However, other copolypeptides of DL-Ala and Leu with different compositions were insoluble in the polymerization system.

The copolypeptides of DL-alanine with Lvaline were insoluble in the polymerization system.
The copolypeptides with highly bulky side chains were soluble in various aprotic solvents. Copolypeptide of ZLys and OBzlAsp with various compositions (No. 20-22, ZLys/ OBzlAsp; $3 / 1,1 / 1,1 / 3)$ were soluble and the copolymers take on the helical conformation. In these copolypeptides, IR absorption was observed at 608 or $610 \mathrm{~cm}^{-1}$, characteristic of $\alpha$-poly(ZLys). However, the $660 \mathrm{~cm}^{-1}$ band due to the right handed $\alpha$-poly(OBzlAsp) was very weak for copolypeptides No. 20 and No. 21.

As described above, poly(ZOrn) is well known as a typical synthetic polypeptide soluble in aprotic solvents. ${ }^{20}$ Copolypeptides of ZOrn with OBzlAsp (No. 23-25, ZOrn/ OBzlAsp; 3/1, 1/1, 1/3) were soluble in the polymerization system and showed a helix content higher than $65 \%$. These copolypeptides were more soluble than homopolypeptide of each component of amino acids. Infrared spectra of these copolypeptides showed the bands characteristic of the $\alpha$-conformation.

It has been reported that poly $(S$-benzyl Lcystein) (poly(SBzlCys)) is in the $\beta$-sheet conformation under various conditions. ${ }^{22}$

The copolypeptides SBzlCys with OBzlAsp No. 28 was soluble and in a helical conformation in dichloroethane. Copolypeptide No. 26 shows strong absorption bands at 1660 , 1640 , and $1630 \mathrm{~cm}^{-1}$, due to the $\alpha, \beta$, and coiled conformations respectively. The spectrum of copolypeptide No. 27 (SBzlCys/ OBzlAsp; 1/1) has strong peaks at 1655,1550 , 660,610 , and $380 \mathrm{~cm}^{-1}$, characteristic of the $\alpha-$ conformation, and has a peak at $440 \mathrm{~cm}^{-1}$ due to the $\beta$-conformation. The spectrum No. 28 film has strong bands at the same wavenumbers as those of No. 27 except for the $435 \mathrm{~cm}^{-1}$ band due to the $\beta$-conformation.

The solubility of polypeptides increases by decreasing aggregation of the polypeptide molecules and increasing solvation to the side chains of polypeptides. The aggregation occurs by intermolecular hydrogen bonding of peptide bonds and hydrophilic interaction of 
side chains. The highly bulky hydrophobic side chains which have high solvation such as carbobenzoxy or benzyl ester in polypeptides increase solubility of copolypeptides in aprotic solvents. The highly bulky side chains must decrease intermolecular hydrogen bonding of polypeptides by steric hindrance. The different bulky side chains of copolypeptides decrease intermolecular hydrophobic interaction between the same side chain, because the smaller side chains cannot interact with each other by the steric hindrance of larger side chains. Based on these results most of the copolypeptides described above have high solubility in commercial solvents such as dichloroethane, dichloromethane, chloroform, benzene, and dioxane.

When a copolypeptide is composed of Dand L- amino acid residues, the ability of aggregation becomes less than that of one composed of D- or L- amino acid only. The irregular conformation due to the DL- segments results in lowering of the intermolecular hydrophobic and hydrophilic interaction. It is expected that the solubility of copolypeptides with DL-conformation is higher than that of all L-, or D-, copolypeptides. However, the solubility of DL-configurational copolypeptides was not higher than that of corresponding all L-, or D-, copolypeptides in aprotic solvents.

Acknowlegments. We wish to thank Dr. Iwakura of Seikei University for useful advice, Dr. Nishi of Hokkaido University for infrared spectra of polymethionine, and Dr. Koizumi of Kyoto University for the film making, and also $\mathrm{Mr}$. Iwatsuki, and $\mathrm{Mr}$. Kayama, Ajinomoto Company for the gift of amino acids.

\section{REFERENCES}

1. E. Katchalski and M. Sela, "Advance in Protein Chemistry," Academic Press, New York, XIII 1958, p 438.

2. H. Yuki, S. Sakakibara, and H. Tani, Bull. Chem. Soc. Jpn., 43, 1788 (1956).

3. C. H. Bamford and H. Block, "Polyamino acids, Polypeptides, and Proteins," M. A. Starman, Ed., Univ. Wisconsin Press, Madison, Wisc., 1962, p 65.

4. M. Oya and R. Katakai, "Shin Jikken Kagaku Koza, Vol. 19-1; Polypeptides," Nippon Kagaku Kai, Ed, Maruzen, Tokyo, 1978, p 244.

5. M. Oya, K. Uno, and Y. Iwakura, "Progress in Polymer Science, Japan, Vol 6; Preparation of Polypeptides and Oligopeptides From $N$-Carboxy Amino Acid Anhydrides in Acetonitrile," K. Uno and S. Onogi, Ed., Kodansha, Tokyo, 1973, p 51.

6. M. Oya and T. Takahashi, J. Polym. Sci., Polym. Chem. Ed., 20, 529 (1982).

7. H. Kyotani, H. Kanetsuna, and M. Oya, J. Polym. Sci., Polym. Phys. Ed., 15, 1029 (1977).

8. H. Kyotani, H. Kanetsuna, and M. Oya, J. Polym. Sci., Polym. Phys. Ed., 16, 367 (1978).

9. J. T. Yang, "Poly- $\alpha$-amino Acids," G. D. Fasman, Ed., Marcel Dekker, New York, 1967, p 239.

10. J. T. Yang and P. Doty, J. Am. Chem. Soc., 79, 761 (1957).

11. K. Matsuura and T. Tsuruta, presented at the Kobunshi Symposium, October 7, 1965.

12. K. Itoh, T. Shimanouchi, and M. Oya, Biopolymers, 7, 649 (1969).

13. K. Itoh, T. Shimanouchi, and M. Oya, Biopolymers, 11, 1137 (1972).

14. E. M. Bradbury, B. G. Carpenter, and R. M. Stephens, Biopolymers, 4, 905 (1968).

15. T. Ozaki, M. Oya, and K. Itoh, Polym. J., 13, 225 (1981).

16. Y. Masuda, Kobunshi Kagaku, 20, 161, 166, 171, 206, and 210 (1963).

17. J. H. Bradbury and B. E. Chapman, Aust. J. Cem., 23, 1801 (1970).

18. G. E. Perlman and E. Katchalski, J. Am. Chem. Soc., 84, 452 (1966).

19. J. Noguchi, S. Tokura, and N. Nishi, Kogyokagaku Zasshi, 69, 745 (1966).

20. R. Katakai and Y. Iizuka, J. Chem. Soc., Chem. Commun., U.K., 1028 (1982); J. Am. Chem. Soc., 106, 5715 (1984).

21. B. Nakajima, N. Nishi, and J. Noguchi, Kobunshi Ronbunshu, 36, 629 (1979).

22. E. R. Blout, C. de Loze', S. M. Bloom, and G. D. Fasman, J. Am. Chem. Soc., 82, 3787 (1960). 